\title{
Partition of India and Migration from the Mymensing District of Erstwhile East Pakistan: A Study of Hajong Tribe
}

\author{
Dr. Adidur Rahman*
}

Associate Prof, Deptt. of Pol. Science, Haji Anfar Ali College, Doboka, Assam, India

DOI: $10.36347 /$ sjahss.2020.v08i02.003

| Received: 20.01.2020 | Accepted: 27.01.2020 | Published: 24.02.2020

*Corresponding author: Dr. Adidur Rahman

\section{Abstract}

The Hajong is a numerically small ethnic tribe of Northeast India with its own rich culture, religion, social customs and traditions. The evidence of the early history of the Hajong tribe is extremely thin. The aboriginal dwelling places of the Hajong are found in Goalpara of Assam in North, Sylhet in South-East of present Bangladesh and in Garo Hills district of Meghalaya. The highest numbers of concentration of Hajong inhibition were found in the hilly areas of North Mymensing district. At the time of partition of the country, the entire Hajong inhabitated areas were annexed with the East-Pakistan. Like many other tribes, the Hajong community became the political victim of the bifurcation of the country. The Hajong tribe which remained in East Pakistan (present Bangladesh) was displaced massively. They were oppressed and suppressed by the majority groups on the one hand and put atrocities by the Government forces of erstwhile Pakistan on the other. Finding no shelter, majority of the Hajong tribe along with other community had left East Pakistan and took shelter in India as refugee. In 1964, about 30,000 Hajong refugees were migrated to India. The Hajongs who were rehabilitated in Arunachal Pradesh, especially in Changlang district are deprived of citizenship rights. The main objective of this article is to identify the causes behind the large scale migration of the Hajong tribe into undivided Assam. The materials for the article are drawn from primary as well as secondary sources like contemporary documents, field investigations, and oral interview with knowledgeable person having information about the Hajong history, polity and society.

Keywords: Migration, displacement, refugee, rehabilitation.

Copyright @ 2020: This is an open-access article distributed under the terms of the Creative Commons Attribution license which permits unrestricted use, distribution, and reproduction in any medium for non-commercial use (NonCommercial, or CC-BY-NC) provided the original author and source are credited.

\section{INTRODUCTION}

The partition of the sub-continent in 1947 and the subsequent emergence of India and Pakistan as two modern sovereign nation states had changed the geo-political landscape of South-Asia forever. The euphoria which had marked the birth of new nation-states was simultaneously accompanied by the cataclysmic partition of the sub-continent resulting in one of the worst incident of human tragedy in recorded history with millions of people becoming refugee. In fact, the first wave of decolonization in South Asia in the late 1940s was accompanied by the largest single bilateral flow of people in the region and also perhaps the biggest refugee movement of the 20th century[1]. A study on the aftermath of partition in South Asia notes-

"across national boundaries in South Asia the view is now widely shared that partition was an 'epic tragedy' that changed the destinies of people in the region. Increasingly, as the long term consequences of partition are becoming manifest, the perception is gaining ground that partition was not just an event but a trigger for a series of reverberation, the tremors of which can still be felt in the region." [2]

${ }^{1}$. Sing, D K. Stateless in South Asia: The Chakmas between Bangladesh and India, New Delhi, Sage Publication India Pvt. Ltd, 2009, p.7.

2. Tan, Tai Young \& Kudaisya, G. The Aftermath of Partition in South Asia' London, Routledge, 2000, p.8. 
The Northeast region of India is ethnically, linguistically and culturally very distinct from the other states of India. At the time of partition, the Northeast region is territorially organized in such a manner that ethnic and cultural specificities were ignored during the process of delineation of state boundaries giving rise to discontentment and assertion of one's identity in the region. As a result, the entire Northeastern region has experienced massive migration and refugee problem including the Hajong tribe.

Flow of Migration from East Pakistan: In the wake of partition, the East Bengal, which became East-Pakistan in 1956, became an integral part of Pakistan. During the period from 1947-1971, large number of people became migrants of India, mostly rehabilitating in some Northeastern states, especially in undivided Assam. Among them, there were some other little known tribes like Santhals, Hajongs, Kochs, Dhalu, Hudis, Morgan, Bannais and Garos were forced to migrate from the North frontier district of East Pakistan. They had migrated mainly from the Mymensing, Rangpur and Sylhet districts of East Pakistan. They were victimsed by both the mob and the state apparatus whenever they demanded for their rights with Pakistani authorities. In order to avoid inhuman torture, they sought shelter on the basis of threat to life due to communal violence gave them refugee status and they had a potential homeland in India [3]. The estimated number of displaced people migrated to India from East-Pakistan may be shown in the following table:

Table-1: Number of displaced persons those who migrated to India as Refugee, 1947-1993:

\begin{tabular}{|lll|}
\hline \multicolumn{2}{|l}{ Table-1: Number of displaced persons those who migrated to India as Refugee, 1947-1993: } \\
From & Year & Numbers.......................... \\
\hline East-Pakistan & $1947-51$ & $1,08,000$ \\
& $1951-61$ & 2.5 million \\
& 1964 & 1 million \\
& 1970 & 2.5 Lakh \\
& 1971 & 10 million \\
& ( $\ldots$ million repatriated) \\
& $1971-81$ & 537 Hindus leaving Bangladesh- \\
& for India every day. \\
& $1981-91$ & 439 Hindus leaving Bangladesh for \\
& India every day. \\
& $1986-93$ & 50,000 Jumma Refugee \\
& (3000 repatriated)
\end{tabular}

Source: Mukherjee. S., 'Indian Experience with Forced Migration: It's Lessons \& Limitations'. (A seminar paper presented at the Conference of scholars \& other professionals working on Refugees and Displaced Persons in South Asia, held in Rajendrapur, Bangladesh, on Feb, 9-11, 1998, p.2.

Hajong inhabitation in North Mymensing District: The history of Hajong tribe is void without the history of their migration. The tribe is the most harassed and afflicted tribe among other little known tribes [4]. As regards the settlements of the Hajongs in the North of Mymensing district, it is said that the areas was settled for the first time by the Hajongs cleansing the dense forest before the advent of any other generation in the area. Scholars conceded that there was large concentration of Hajong people in East Bengal (present Bangladesh) during the pre-partition days of India. The Hajong inhabitation were said to have bounded by Suwarkuna village in the north near Lakhipur of Goalpara district of Assam by Jamkona or Jongkona village in the South East, now in Sylhet district of Bangladesh and by Morkona village in the West Garo Hills district and near Mankacher of Assam. In this periphery of Hajong habitation the region from Mahiskhola to Laochapara- Bahadur kata near Mahengraganj in the border of composite Garo Hills and Bangladesh, the Hajong habitations were compact and concentrated. From Mohiskhola to Laochapara about $1440 \mathrm{sq}$. km. of areas of land patch was predominantly inhabited by the Hajongs and the Garos [5]. The following Census report of 1891 shows the concentration of the Hajong tribe in the region:

${ }^{3}$. Zolberg. A. R. ,Suhrke. A. ,\& Aquayyo. S. Escape from Violence: Conflict and Refugee Crisis in the Developing World,' Oxford, Oxford University Press, 1989, pp. 132-135.

4 . Sheikh, E Ali. Hajong Janoghosti, Assam: Goalpara, Moromi Printers, 2012 p. 266.

5 . Ibid. , 
Table-2: Census Report, 1891

\begin{tabular}{|l|l|l|l|l|}
\hline & District & Male & Female & Total \\
\hline & Cacher(plains) & 242 & 243 & 485 \\
\hline \multirow{5}{*}{ PLAINS } & Sylhet & 1516 & 1289 & ---- \\
\cline { 2 - 5 } & Surma Valley total & 1516 & 1289 & 2805 \\
& Goalparta & 195 & 202 & \\
& Kamrup & 1 & ----- & \\
& Darrang & 7 & ----- & \\
& Nowgong & 3 & ----- & \\
& Sibsagar & ---- & ---- & \\
& Lakhimpur & ---- & ---- & \\
\cline { 2 - 5 } & Total Brahmaputra Valley & 206 & 202 & 408 \\
\hline \multirow{5}{*}{ HILL } & Total in plains & 1722 & 1491 & 3213 \\
\hline & Khasi Jaintia Hills & 164 & 131 & \\
& Garo Hills District & 2720 & 2538 & \\
\cline { 2 - 5 } & Total Hill Districts & 2884 & 2669 & 5553 \\
\hline & Total in Entire Regions & 4606 & 4160 & 8766 \\
\hline
\end{tabular}

Source: Allen, B C 1891, Census Report, Vol. 1, p.29

Flow of migration of the Hajong Tribe: The problem of migration between India and East Pakistan started as early as the partition of the country in 1947 and arrived its climax in 1964. The large scale flow of migration of the Hajongs from the North Mymensing district of erstwhile East Pakistan may be attributed of the following factors:

1. Demand for Amalgamation with India: There was a relentless effort even before the partition of the country in the North Mymensing district by Hajongs to amalgamate the 'Partially Excluded Areas' with the Indian Union. The long arduous struggle for freedom had reached at its climax with the acceptance of the proposal of the 'Cabinet Mission' made at Shimla on 3rd June 1947 to attain independence at the cost of partition of the country. The Boundary Commissionsone for Punjab and other for Bengal with Cyril Radcliffe as chairman of both the Commission were constituted. During those fateful days, the demand was made by the Hajongs to incorporate the partially excluded areas of Bengal with the Garo Hills district. The background of demand was the concentration of the majority Hajong people in the said areas [6]. In order to fulfill their demand of amalgamation of their territory with the Indian Union, the Hajong communities submitted two important memorandums to the then Congress President Acharya J. B. Kripalani and Jawaharlal Nehru respectively. The Hajong representatives like Sri Monoranjan Roy Hajong, Sri Dinesh Chambugong (later on Sangma), Rohini Madhav Jowardar, Moni Sarkar, Narendra Chandra Sarkar and Dipendra Sarkar took active part for submitting the memorandums[7].

Sri Monoranjan Roy Hajong along with other Hajong representatives expressed profound grief and discouraged by the award accorded by Radcliffe as Chairman of the Commission. They found the declaration was a one- man job and to be a mere show to appease some aggrieved people. Despite their repeated efforts the demand for annexation with the Indian union of the entire North-Mymensing region was left unfulfilled. The fate of the Hajong tribe was sealed for good in to an abysmal darkness. Monoharan Hajong, an inhabitant of Kalmakanda of the erstwhile East-Pakistan, Presently living in Matia camp- 11 in Goalpara district, expressed his anguish during interview and said,

"the Hajong people were worst affected along with other tribes by the bifurcation of the country in 1947. The Hajong People are peace loving people and were mainly concentrated in the Mymensing and Sylhet district of the East Bengal. The freedom fighters had tantalized the whole Hajong people. Our forefathers supported the freedom movement in order to free the country from the clutch of the mighty British Raj. But who knew that we were merely fighting to shift from foreign to another foreign government. The appeal and memorandums submitted by our people to amalgamate our land with the Indian Territory was turned down without assigning any reasons. But the leaders poured cold water to our long cherished dreams and plunged into grief the whole Hajong tribe and which helped the anti-people government to displace us forcefully from our land (East Pakistan) [8].

6 . Hajong, B, The Hajongs and Their Struggles, Meghalaya, Hawakhana, Tura, 2000, P.70.

7 . Ibid.

8 . Monoharan Hajong, Matia camp-II, District- Goalpara, Assam 
Sir Cyril Radcliffe, the man who was entrusted the job to demarcate the boundary between India and Pakistan had never visited British India before and had absolutely no idea about the complexity of the ethnic make-up or the varied cultural practice of the numerous communities inhabiting this colonial territory. As stated by Tan and Kudaisya (2000: 94),'Radcliffe knew only too well that this had been a butcher's job, and not a surgeon's operation, and that his rushed job of an award would please no one.' To quote from one of the letters he wrote to his stepson on the eve of his departure fr4onm India: 'Nobody in India will love me for the award about Punjab and Bengal and there will be 80 million people with a grievance who will begin looking for me. I do not want them to find me' 9 . These words of Radcliffe proved ironically prophetic for the millions of refugee including the Hajongs tribes.

It becomes abundantly clear that due to the inclination of the Hajongs and other minority tribal communities inhabiting in strip of land of North-Mymensing district were regarded as anti-Pakistani and disloyal to the authority of the Pakistani government. In retaliation countless inhuman torture was meted out on the Hajong tribe by the EastPakistani armed forces. The Hajong tribe along with others had migrated to India crossing international border to save their life.

2. Demand for Adhisthan (Tribal land): Even long before the partition, there was a demand to form a separate state known as 'Adhisthan' [10] by the Hajongs in the partially excluded areas of East- Bengal. They raised their demand under the leadership of Mr. White, the father of the Baptist Mission, Birisiri (Durgapur Police Station). The tribes managed to convince the leaders like Amrit Kaur, A. K. Azad of the Indian National Congress about their demand for ' Adhisthan' Moreover, the demand of the Hajongs was supported on the basis of the Census Report, 1941[11].

Since the day of denial of their demand by the boundary commission, the incidence of inhuman atrocities and extortions increased more on the tribes including the Hajong tribe as anti-national in their areas. As a result, in order to avoid atrocities at the hand of the East- Pakistani forces a large number of Hajong tribe had left their native place and migrated to India especially in the years 1949, 1950, 1964 and in 1971[12]. The East-Pakistani government had created a rare example in human history by declaring these indigenous tribes as 'enemy'[13].

3. Religious Discrimination: The partition of Indian sub-continent in 1947 and subsequent communal clashes that caused massive migration of minority communities from the erstwhile East Pakistan to India. Majority of the tribal land of Garos, Koch, Dhalus and Hajongs along the border strip of the Mymensing district were incorporated with the East Pakistan mainland. Because of their religious differences majority of the tribe migrated to India after partition of the Indian sub-continent [14]. The Hajongs follow a religion similar to Hinduism. According Ahmed Rafiq, "in terms of religious beliefs Hajongs are close to Hindus, Hajong worship Durga and other Hindu Gods and Goddesses. But Shiva is their chief deity. They observe a number of bratas (vows) including the kartik brata performed in the month of kartik (October-November). Girls and women dance and sing in brata ceremonies. Hajong also worship the Brahmaputra River. Like Hindu Brahmin, Hajongs wear paita (the holy thread) on their bodies. Hajong are believers in incarnation too[15]. In fact, religious cult was one of the factors of migration of Hajong from the East Pakistan.

4. Communal Tensions: The communal violence that broke out in the wake of the partition of Indian sub-continent had left an indelible black mark in its history. The communal disturbances may be attributed as another cause of cross border migration of Hajongs. The Muslim League Government acted on two main objectives-the exploitation of the East Pakistan and the other is to drive away the religious minority communities from the East Pakistan. In fact, the acute antiHindu policy of the Muslim League was responsible for the outbreak of communal riot in 1950[16]. The communal tension was responsible for the flow of migration between both the countries. But the flow of migration reached its highest number in 1964. Biren Hajong (2000) stated that about 60,000 Hajongs inhabitants and a great chunk of them forced to evacuate their native villages from the East-Pakistan. As per records, between 1964-71, average in every year 1, 96,296 numbers of refugees including the Hajong migrated to India from the East Pakistan.17 Urmila Hajong narrated their tale very succinctly during interview that:

9 . Tan and Kudaisya, op. cit., p. 94.

${ }_{11}^{10}$ Sheikh ,E A,op.cit.p.259.

11 . Hajong. Nikhil. Roy. "Hajong der Artha-Samajik Abaster Botaman Parjaya”.Smoranika,( in Bangla), Birisiri.1987, P. 20 .

12. Sheikh ,Ibbat. Ali,op.cit.p.259.

13 ."The Hindu Minority in Bangladesh" The Assam Tribune, $18^{\text {th }}$ January, 2000.

${ }^{14}$.Kim, Amy. et. al. The Hajong of Bangladesh: A Socio-Linguistic Survey, SIL International, Electronic Survey Report, 2011, P.11.

15 .Ahmed, Rafik, Banglapedia : National Encyclopedia of Bangladesh, 'Dhaka, Asiatic Society of Bangladesh, 2003, p.490.

16 .Ibid, p. 140 .

17 . 'The Hindu Minority in Bangladesh', The Assam Tribune, Jan, 18,2000, 
“....in fact, our (Hajongs) destiny became bleak before the British had left the country. The situation turned worse since the days of the partition of the country. Many of our relatives and other tribes and communities had left their villages and migrated to India. But still we determined and tried to stay in East-Bengal (Mymensing District) despite repeated attack on our tribe. But the communal violence that broke out in 1964 (approx) forced us (Hajongs) to leave behind our native village abandoning our homeland and valuable properties [18].

5. Arrival of Bihari Muslims (Muhazirs) Refugees to East-Pakistan: The arrival of large numbers of Bihari Muslims (Muhazirs) from the state of Bihar and Assam to East Pakistan also responsible for the forced displacement causing migration of the Hajong tribe. It is to be noted here that Muhazirs are the Bihari Muslim refugees migrated to East Pakistan from India as a result of communal violence. The impact of communal violence that broke out in March-April, 1950, at Khulna, was large scale exodus of Urdu speaking Muslims (Muhazirs) from Bihar and Assam to East Pakistan[19]. There are also reports that there was an in-flow of Urdu-speaking migrants from West Bengal to the East Pakistan. According to an estimate furnished by Ahmed [20]. by 1951, Urdu speakers accounted for about 20 percent of the total population of East Pakistan. The Government adopted dual strategies to tackle the rehabilitation issue of the migrated Muhazirs. The first was the rehabilitation of Muhazirs in the tribal occupied land and the second was to cause force exodus of the recalcitrant insurgent peasants like Hajongs, Garo, Dhalus and other tribes. As per the plans, the Muhazirs were pushed towards the North-Mymensing aborigines areas with pretext or plea to uproot the Hajongs and other indigenous tribes. Despite stiff opposition, Pakistani police used 7 to 8 elephants [21] to evict the lands of the tribal peasants. Besides, the Government forces instigated the Muhazirs against the tribes to capture their land and to snatch away their valuable properties.

As per the hidden plan of the Government, the Muhhazirs who migrated first were rehabilitated in each village under Susang-Durgapur and Kolmakanda police stations [22]. However, the large flow of Muhazirs from Assam in the month of March-April, 1950 deteriorated the situation more badly increasing the amount of harassment on the tribes including the Hajongs. They were forcibly rehabilitated into the densely populated villages of aboriginal peasants under the police stations of Haluaghat, Nalitabari and Sribardi. There are reports that about 150 villages were evicted entirely to accommodate the Muhazirs which included- Panchgaon, Kharnoi, Chaityanna Nagar, Langura, Jigtola, Haluaghat, Vehikura, Maizpara, Ghoshgaon, Gajirbhita, Bhavankura, Jugali, KakorakandiManpara, Bokura, Kangsa, Jinaigha[23]. etc. Besides, a number of Hajong villages were evicted partially for rehabilitation of Muhazirs in the northern borderland strip of Mymensing district. In the midst of protest, all the peasant leaders and youths were apprehended and jailed without any trial. The amount of inhuman torture was so horrible that had left 25 tribal peasants death inside the jail[24]. The Government's decision to rehabilitate these Muhazirs into the north Mymensing regions was also responsible for the migration of the Hajong tribes.

\section{Impact Communist Movement}

The real cause behind their migration was found the growing involvement of the Hajongs in the militant peasant movement under the auspices of the communist party. In fact, Hajongs supported communist party to fight against the exploitation of the zaminders of the North Mymensing district and to prevent the atrocities of police thanas on the Hajong peasants. They even threatened to dare the Thanas [25] in their region. The whole Hajong inhabited areas were influenced profusely by the wave of communist movement under the West Bengal Kissan Sabha. The movements like Tonko Movement, Tebhaga, Hati Kheda Begar system were dominated by the communist party leaders of the Hajong tribes against the exploitation by zaminders. Some of the communist party leaders namely, Lalit Sarker Hajong, Sachin Hajong(Bharatpur) ,Prasanna Hajong, Jehal Hajong, Jameswar Hajong, Monmohan Hajong, Birat Hajong, Tanuram Hajong, Kangal Das Hajong, Rasendra Hajong, Biswerswar Hajong, Nayan Hajong[26] etc. struggle for the peasants against the zaminders. In order to suppress the communist movements and theirs leaders, the East Pakistani forces started

18 . Informant-Urmila Hajong (67),W/O- Lt, Joggeswar Hajong, Matia, Camp-1, Goalpara, Assam.

${ }^{19}$. Gupta, Promot, Mukti Juddhey Adivasi, Calcutta, Manisha Library, Pvt. Ltd, 1963, P.116.

${ }^{20}$. Ahmed, Rafiuddin, ed, Religion, Nationalism and Politics in Bangladesh, New Delhi, South Asian Publishers, 1990 , pp.13-14.

21. Gupto, Promot, Jey Sangramer Ses Nei, ( Bengali) .Calcutta, New Age Printers, 1971, p.179.

22 .Gupta, Pramath,. op.cit. p.139.

${ }^{23}$. Ibid, p. 116.

${ }^{24}$. Ibid,. p. 117.

25. Sonowal, K, "Tribes of North East India" Global Journal for Research Analysis, Vol.3, Issue 2, Feb, 2014 , p.8.

26 . Hajong. Biren, op.cit. p.68. 
combing operation to nab the ring leaders. Majority of the leaders migrated to India to escape the police arrest. The following table (3) also corroborates the response of the respondents about the causes of their migration:

Table-3: Response on the Migration of the Hajongs from the erstwhile East Pakistan

\begin{tabular}{|l|c|c|}
\hline Causes & Respondents & \% \\
\hline Voluntary & 4 & 1.18 \\
\hline $\begin{array}{l}\text { Communal } \\
\text { Conflict/violence }\end{array}$ & 196 & 57.65 \\
\hline $\begin{array}{l}\text { Religious } \\
\text { Discrimination }\end{array}$ & 50 & 13.74 \\
\hline Land Transfer Deal & 19 & 5.59 \\
\hline Political Violence & 25 & 7.35 \\
\hline Others & 1 & 0.29 \\
\hline Total Respondents & 340 & \\
\hline
\end{tabular}

Source: Field data generated by the author

It becomes amply clear that the Hajongs were the victims of the bifurcation of the Indian sub-continent. They became the target of the communal violence that broke out in East Pakistan in 1950s again in 1964 and later in 1971. During field study it is found that majority of the respondents of Assam, Meghalaya and Arunachal Pradesh displaced forcibly from Northern Mymensing and Sylhet district in 1964. Tarun Sen, a renowned writer commented on the plight of the People of East Pakistan which reads:

"...hardly there could be a single country in human history, where freedom fighters were declared as traitors, tortured and oppressed and jailed after spending 200 years under foreign domination. During the last 20 years, these type of heinous crime happened in front of our eyes. The people of Pakistan could not enjoy the taste of independence for a single day". (Promoth, Gupto, 1971. pp. 109-110).

The influx of refugees from the East Pakistan constitutes the biggest migration stream into Assam during the decade of 1941-51. Following the Noakhali disturbances in 1949 and partition of India, there had been steady exodus of refugees from East Bengal into Assam. The arrival of refugees into Assam till 1951 may be presented in the following Table:

Table-4: Arrival of Refugees from the erstwhile East Pakistan into Assam, 1946-1951.

\begin{tabular}{|l|c|}
\hline Year & No of Refugees \\
\hline 1946 & 6,860 \\
\hline 1947 & 42,346 \\
\hline 1948 & 41,740 \\
\hline 1949 & 33,138 \\
\hline 1950 & 144,512 \\
\hline $1951($ Jan \&Feb) & 3,479 \\
\hline Total & 272,075 \\
\hline From West Pakistan & 647 \\
\hline District of origin not known & 1,733 \\
\hline Grand Total & 274,455 \\
\hline
\end{tabular}

Source: Census of India, 1951, Assam, Manipur and Tripura, p.359.

It is to mention here that the continuous flow of refugees increased after the partition of the country into undivided Goalpara district of Assam. In 1951, about 44,967 numbers of refugees took shelter in Goalpara [27]. Again 23,611 families registered their name in Goalpara district in 1955-56. In this way the numbers of refugees increased to 85,946. Among the 23,611 families which arrived in 1955-56, about 2827 families were sheltered in town areas of Dhubri sub-Division (2544) and Goalpara Sub-Division (283) families. The remaining 20,784 families provided sheltered in village areas of both the Sub-Divisions. The rehabilitated places and the numbers of their families may be shown in the following table:

27. Sheikh, Ohijuddin. 'Kukrajharer Ghusti Sangarsha Aru Kisu Prasangik Katha, in M. Abdul (ed)'Ayna', vol. 1. No:X11, Guwahati, 2013, P.18. 
Table-5: Settlement of Refugees in Dhubri and Goalpara sub-divisions

\begin{tabular}{|l|l|l|}
\hline Name of Sub-Division & Place of Settlement & No. of Families \\
\hline Dhubri Sub-Division & Dhubri & 711 \\
\cline { 2 - 3 } & Bilasipara & 1931 \\
\cline { 2 - 3 } & Gulaokganj & 2948 \\
\cline { 2 - 3 } & Gusaigaon & 1315 \\
\cline { 2 - 3 } & Kokrajhar & 2318 \\
\cline { 2 - 3 } & Mankachar & 395 \\
\cline { 2 - 3 } & South Salmara & 542 \\
\cline { 2 - 3 } & Total & 10,160 \\
\hline Goalpara Sub-Division & Goalpara & 494 \\
\cline { 2 - 3 } & Dudhnoi & 747 \\
\cline { 2 - 3 } & Lakhipur & 668 \\
\cline { 2 - 3 } & North Salmara & 4239 \\
\cline { 2 - 3 } & Sidley and Bijnee & 4476 \\
\cline { 2 - 3 } & Total & 10624 \\
\hline
\end{tabular}

Source: Gazetteer of India, Assam, Goalpara District, Govt. of Assam, Guwahati, 1979.

In fact, more than 75,000 refugees from East Pakistan arrived into Assam within one and half months since the genocide began in 1964. The refugees, mostly Garos, Hajongs and Dalus from Mymensing took refuge in Garo Hills of Assam, now in Meghalaya [28]. By 28 March, 1964, around 78,000 tribal refugees had migrated from Mymensing district of East Pakistan. According to the Government of India estimate, by the middle of 1964, at least 1, 40,000 persons including Hajong and Chakmas consisting of 2902 families had migrated to Assam. The community wise numbers of refugees accommodated at different camps under Dalu area in 1964 [29] may be shown under the following table:

Table-6: Community wise Refugees at Various Camps under Dhalu Area in 1964.

\begin{tabular}{|c|c|c|c|c|c|c|c|c|c|c|c|c|c|}
\hline \multirow{2}{*}{$\begin{array}{l}\text { SL. Name of } \\
\text { No. Refugee Camp }\end{array}$} & \multicolumn{2}{|c|}{ General } & \multicolumn{3}{|c|}{ Backward Classes } & \multicolumn{5}{|c|}{ Scheduled Caste } & \multicolumn{3}{|c|}{ Schedule Tribes } \\
\hline & Bengali & Bihari & Koch & Banai & $\begin{array}{l}\text { Raj- } \\
\text { Bongshi }\end{array}$ & Dalu & Barbar & Sweeper & $\begin{array}{l}\text { Fisher- } \\
\text { man }\end{array}$ & Cobbler & Garo & Hajong & Total \\
\hline 1. Machangpani & 322 & 26 & 201 & 21 & ----- & 701 & 30 & 5 & 47 & 25 & 4008 & 1638 & 7024 \\
\hline 2.Bhogai & 450 & 297 & ---- & 67 & 170 & 683 & ---- & ---- & ---- & 8 & 3958 & 1336 & 7077 \\
\hline 3. Chandabhoi & 6 & 16 & 474 & --- & 2 & 48 & ---- & 9 & 9 & 9 & 609 & 1626 & 2849 \\
\hline 4. Bilkona & 309 & 43 & --- & 332 & - & 9 & ---- & ---- & ---- & ---- & 5319 & 1158 & 7167 \\
\hline 5. Deplipara & 29 & ---- & ----- & ----- & 5 & ---- & ----- & ----- & ----- & ----- & 1400 & 2042 & 2476 \\
\hline 6. Maghupara & 438 & ----- & 2304 & 481 & 37 & 710 & ----- & 16 & 16 & 6 & 1429 & 3829 & 9291 \\
\hline 7.Mineng & 163 & 201 & 120 & ---- & 26 & 1051 & ----- & 66 & 66 & 34 & 3506 & 129 & 5296 \\
\hline 8.Dindini & --- & ---- & 27 & 5 & ---- & 25 & ----- & --- & ----- & ----- & 7392 & 20 & 7469 \\
\hline 9.Dalu & 17905 & 5001 & 991 & -- & 1003 & ---- & --- & ---- & ----- & 500 & 5019 & 3064 & 33483 \\
\hline Total & 19619 & 5584 & 4117 & 906 & 1243 & 3227 & 30 & 96 & 96 & 582 & 232640 & 13842 & 82132 \\
\hline
\end{tabular}

Source: File no. GRRO 1/64/..Accommodation of Refugees, D.C. Office, West Garo Hills, Tura

Moreover, Bangladesh Liberation War of 1971 also compelled the Hajongs, Garos and others to cross the international border and took shelter on the Indo-Bangladesh border of Garo Hills of Meghalaya. Every day hundred and thousands of refugees flooded into Garo Hills from 26 March, 1971 till December 1971. But the highest number was recorded in the Governments record was 2, 82,947 as on 9 December, 1971.30 Religion wise their numbers in these camps may be shown in the table:

${ }^{28}$. Bhattacharya, S K. Genocide in East Pakistan/Bangladesh, Houston, Ghosh Publisher,1987, p.108.

${ }^{29}$. File no. GRRO 1/64/...Accommodation of Refugees, D.C. Office, West Garo Hills, Tura.

${ }^{30}$. Sangma, S N. Bangladesh Immigrants in Meghalaya, Delhi, Anshah Publishing House 2005 p.60. 
Table-7: Religion wise Refugee classification in different Camps, 1971 (As on 7.08.1971)

\begin{tabular}{|l|l|l|l|l|l|}
\hline $\begin{array}{l}\text { SL. } \\
\text { No }\end{array}$ & Name of Camps & Hindus & Muslims & Others & Total \\
\hline 1 & Dalu(Barenggapara ) & 1,352 & 6 & 366 & 1724 \\
\hline 2 & Vety. Compund Dalu & 3,930 & 1,037 & 1286 & 6,253 \\
\hline 3 & Chandabhoi & 5,573 & 1,156 & 1,290 & 8,019 \\
\hline 4 & Sisengpara & 2,985 & 852 & 1,799 & 5,633 \\
\hline 5 & Halchati & 2,125 & 2 & 584 & 2,711 \\
\hline 6 & Machangpani & 3,985 & 26 & 939 & 4,923 \\
\hline 7 & Dimapara & 5,037 & 1,934 & 8,352 & 15,323 \\
\hline 8 & Puraldiasa & 5,086 & 737 & 2,100 & 7,923 \\
\hline 9 & Baghmara & 34,682 & 2,772 & 16,390 & 53,844 \\
\hline 10 & Sibbari & 7,138 & 1,713 & 5,864 & 14,715 \\
\hline 11 & Bilkona & 48 & 3,604 & 4,022 & 7,674 \\
\hline 12 & Mineng & 433 & 1,971 & 5,124 & 7,528 \\
\hline 13 & Mahendraganj & --- & ---- & --- & ---- \\
\hline 14 & Kalipara & 15,637 & 7,929 & 490 & 24,056 \\
\hline 15 & Patijora & --- & ---- & ---- & ---- \\
\hline 16 & Ampati & 3,074 & 8,221 & 12 & 11,307 \\
\hline & Total & 91,098 & 31,960 & 48,618 & $1,71,636$ \\
\hline
\end{tabular}

Source: Sangma, S N 2005, Bangladeshi Immigrants in Meghalaya, Anshah Publishing House, Delhi, p. 28.

It may be noted from the above table that some other tribes including the Hajongs were included in the Hindu refugees groups. The evacuees started to take shelter in the Garo Hills from 26/03/1971 onward till February 1972. Daily records show that there were continuous flow of evacuees since March 1971 and which lasted up to 9/12/1971. Sheikh (2012) has presented an elaborate demographic profile of the rehabilited Hajong population and their inhabitation in India and the Hajong population of Bangladesh based in the year 1996 and 200631 respectively which may be presented in the following table:

Table-8: Hajong Habitation and their Population-

\begin{tabular}{|c|c|c|c|c|c|}
\hline & & & 1996 & 2006 & Total \\
\hline \multirow{25}{*}{ India } & \multirow{18}{*}{ Meghalaya } & Goalpara & 22,483 & & \\
\hline & & Dhemaji & 8,910 & & \\
\hline & & Dhubri & 8,466 & & \\
\hline & & Lakhimpur & 5,102 & & \\
\hline & & Nagaon & 3,776 & & \\
\hline & & Kamrup & 3,480 & & \\
\hline & & Tinsukia & 1,871 & & \\
\hline & & Darang & 1,850 & & \\
\hline & & Nalbari & 1,707 & & \\
\hline & & Bongaigaon & 1,176 & & \\
\hline & & Karbi- & & & \\
\hline & & Anglong & 386 & & \\
\hline & & Barpeta & 350 & & \\
\hline & & Sunitpur & 302 & & \\
\hline & & Dibrugarh & 136 & & \\
\hline & & Kokrajahr & 7 & & 60002 \\
\hline & & Garo Hills & ----- & 55,902 & \\
\hline & & Khasi Hills & $\begin{array}{ll}----- \\
-1\end{array}$ & 9,722 & 65,624 \\
\hline & \multirow{3}{*}{$\begin{array}{l}\text { Arunachal } \\
\text { Pradesh }\end{array}$} & Changlang(Miao) & $\begin{array}{ll}---- \\
\end{array}$ & 11,000 & \\
\hline & & Lohit & ----- & 11,000 & \\
\hline & & Tirap & $\begin{array}{ll}---- \\
\end{array}$ & 11,000 & 33,000 \\
\hline & Tripura & ------ & $\begin{array}{ll}---- \\
\end{array}$ & 2,500 & 2,500 \\
\hline & West Bengal & Jalpaiguri & $\begin{array}{ll}---- \\
\end{array}$ & 3,000 & 3,000 \\
\hline & $\begin{array}{l}\text { Madhya } \\
\text { Pradesh }\end{array}$ & Dandhakaranya & $\begin{array}{ll}----- \\
\end{array}$ & 3500 & 3,500 \\
\hline & $\begin{array}{l}\text { Andaman } \\
\text { Islands }\end{array}$ & Portblair & 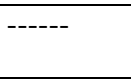 & 900 & 900 \\
\hline \multirow{2}{*}{ Bangladesh } & & Mymensing & & 17,600 & \\
\hline & & Sylhet & & 2,280 & 19,880 \\
\hline Total & & & & & $1,88,406$ \\
\hline
\end{tabular}

Source: Sheikh, I. A., (2012), 'Hajong Janoghosti' Moromi Printers, Goalpara, Assam p.50.

31 . Ibid. ,p.50 
The above analysis of data and circumstances reveal the root cause of displacement resulting forced migration of the Hajong tribe that took place from North of Mymensing district in different phases. After the partition of the country, majority of the displaced Hajongs tribe were rehabilitated in different parts of Assam, Arunachal Pradesh, Tripura, Madhya Pradesh, West Bengal and Andaman and Nicobar. Except Arunachal Pradesh, the migrated Hajong tribe were rehabilitated and awarded Indian citizenship rights with ST status. In Arunachal Pradesh the Hajong tribe are still fighting for their citizenship status and living a stateless refugee life. 